\title{
ELECTRICAL PROPERTIES OF GAMMA-MODIFIED COMPOSITES COPOLYMER OF POLYVINYLIDENE FLUORIDE WITH TETRAFLUOROETHYLENE AND SILICON
}

\author{
I.M. Nuruyev \\ The Institute of Radiation Problems of ANAS, AZ 1143, Baku, Azerbaijan \\ E-mail: nuruyevibrahim@gmail.com
}

The concentration and temperature dependences of the electrical properties of the composites obtained on the basis of a copolymer of polyvinylidene fluoride with tetrafluoroethylene P(VDF-TFE) with silicon nano- and microparticles were investigated, and the effect of gamma-radiation on them was studied. It is shown that the cause of the change in the concentration and temperature dependences of the electrical properties of irradiated composites $\mathrm{P}(\mathrm{VDF})-\mathrm{TeFE}) / \mathrm{Si}$, apart from crosslinking and destruction, is the uneven distribution of the energy of the absorbed radiation between the components of the composite material.

PACS: 61.80.Ed; 61.25.hp; 72.80.Tm

\section{INTRODUCTION}

Recently, physics and chemistry of nano-sized materials are one of the most intensively developing fields of science and technology [1-4]. In this connection, of great interest are studies of composites based on a polymer with a semiconductor, the processes occurring in them, and size effects [5-7]. It is also associated with their electrophysical, physico-chemical, optical, and photoproperties and their practical application in various devices (photocells, solar cells, sensors etc.). It is possible to control its electrophysical, optical and photoproperties by changing volume quantity and size of filler in polymer composites.

The composite materials have different active properties depending on the type and properties of the filler [8-12]. On the other hand, various external effects, including ionizing radiation, can modify these active properties [13-16]. Scientific studies in this direction show that composites with semiconductor fillers are of great interest. Interest in these composites is due to the presence of electroactive properties with a wide spectrum in the semiconductor materials. Electroactive properties of such composites are mainly formed by electrical properties, and the current value in the composites is determined by the sizes of the polymer layer between the filler particles, and the Volt-Ampere Characteristics (VAC) due to tunneling of the charge carriers from this layer $[17,18]$. Despite the large number of scientific studies on the investigation of electrophysical properties in these materials, the value of interparticle contact resistance and the beginning of the percolation border in composites are insufficiently studied [19-22]. Also, here the effects of ionizing radiation on these problems have been examined in superficial. Considering these, in the present work, different volume composites were obtained on the basis of nano- and microsilicon (Si) particles and copolymers of polyvinylidene fluoride with tetrafluoroethylene. First of all, the concentration and temperature dependence of specific volume resistance of composites irradiated with gamma-quantum doses in various doses were studied. Then, the temperature dependence of the specific volume resistance of the $\mathrm{P}(\mathrm{VDF}-\mathrm{TeFE}) / \mathrm{Si}$ nano- and microcomposites with contains 1 and $10 \%$ volume was irradiated in the dosage range of $0 . .300 \mathrm{kGy}$.

\section{EXPERIMENTAL PART}

The composites are obtained by thermal pressing method of previously mixed powders in definite volume component ratios. Pressing is carried out at the melting point of the polymer matrix under a pressure of $10 \mathrm{MPa}$ for $5 \mathrm{~min}$, followed by cooling the melt in an aqueous medium at an ice temperature. The resistance measurement of composite samples is carried out by E6-13A Theraohmmeter at heating rate $2.5 \mathrm{~K} / \mathrm{min}$. The samples in "sandwich" form with plane-parallel electrodes from aluminium are used for measurement of $\rho_{\mathrm{v}}$ specific volume resistance. Samples were irradiated with a source of $\gamma$-radiation based on the ${ }^{60} \mathrm{Co}$ isotope on the MRX- $\gamma-25 \mathrm{M}$ facility.

\section{DISCUSSION OF THE RESULTS}

As known, the electrical properties of the composites are dependent on interparticle contact resistance, resistance of components, type, size and quantity of filler [23]. From the dependences (Fig. 1,a,b) it is clearly seen that the change in the volume amount of the filler up to $50 \%$ in the composite, there is a change in the resistance $\rho_{\mathrm{v}}$ of approximately $\sim 5$ orders of magnitude, which is typical of heterogeneous composite systems. The separation of the electric conductivity to the dielectric at the low concentrations of filler and high conductivity regions at high concentrations is typical for polymer-filler composite systems. The interval between two areas where the resistance is monotonously decreases is called the percolation zone. Various external factors also affect the change in electrical properties of composite materials, and sometimes these factors allow you to control their properties. The effect of the ionizing radiation we use as an external factor leads to the certain changes in the electrical properties by changing the structure of composite components and the nature of the interphase boundary.

It has been given the concentration dependence $\lg \rho_{v}=f(\Phi)$ of the specific volume resistance of the $\mathrm{P}(\mathrm{VDF}-\mathrm{TeFE}) / \mathrm{Si}$ composites, initial and irradiated at different doses, which was taken on the basis of fillers with the size of $d<50 \mu \mathrm{m}$ (a) and $d \sim 50 \mathrm{~nm}$ (b) (see 
Fig. 1). Apparently, the percolation transition is observed in the concentration range of $\sim 5 \ldots 20 \%$ by volume of filler (curve 1) for composite P(VDFTeFE)/micro-Si (see Fig. 1,a). In addition to narrowing the range of the percolation transition in samples irradiated with gamma rays with $100 \mathrm{kGy}(\sim 10 \ldots 20 \%$; curve 2), this range doubles with increasing dose $(D)$ and the beginning the percolation transition shifts towards higher filler values (curves 3 and 4). We believe that the observed effect is due to cross-linking processes between the macromolecules of the polymer and the polymer chains with the surface of the $\mathrm{Si}$ particles. The intermolecular crosslinking processes in the matrix due to the influence of gamma irradiation at

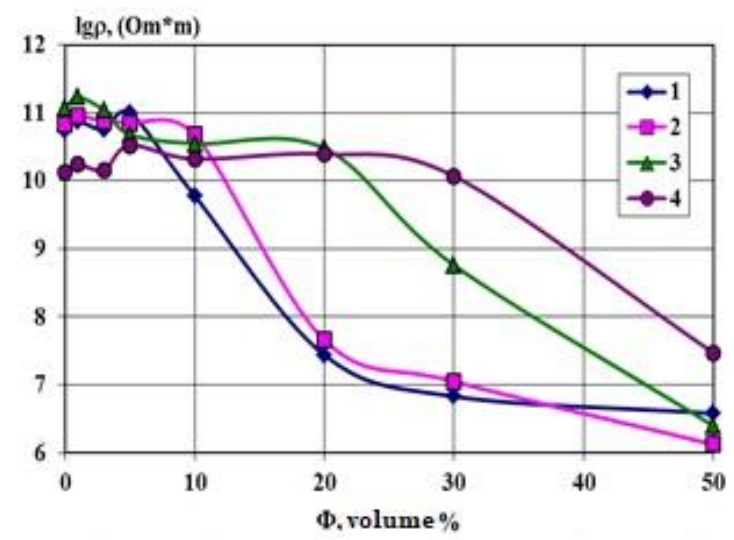

$a$

lower values of the filler provide a decrease in the mobility of macromolecular chains and the relative stability of the electrical resistance of the composite.

In my opinion, another reason why the electrical resistance of the composite remains relatively high and constant is oxidation of the surface of Si particles during the radiation on the open air. Crosslinking on the matrix and oxidation of the filler surface are the factors that observed the percolation transition boundary causes the filler to move towards higher filler values in gammairradiated samples. A subsequent increase in the amount of filler in the matrix leads to a relatively large decrease and stabilization of the resistance value due to contacts between the particles.

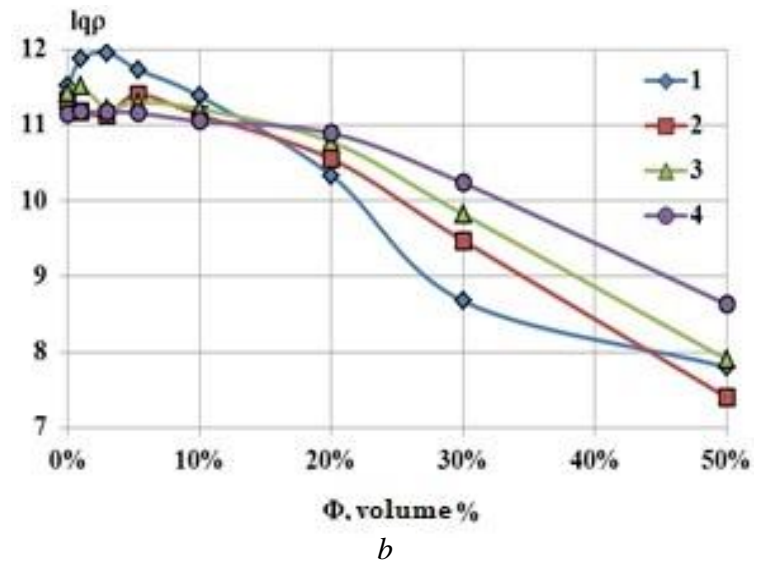

Fig. 1. Dependence $\rho_{v}=f(\Phi)$ of $P(V D F-T F E) /$ nano-Si composites, initial and irradiated at different doses, obtained on the basis of fillers with the sizes of $<50 \mu \mathrm{m}(\mathrm{a})$ and $d \sim 50 \mathrm{~nm}(\mathrm{~b})$ :

1-initial; 2 - irradiated at 100 kGy; 3 - $200 k G y ; 4-300 k G y$

It can be seen that the dependence $\lg \rho_{\mathrm{v}}=f(\Phi)$ of the initial and irradiated composites P(VDF-TeFE)/nano-Si obtained at different doses, based on fillers $(d \sim 50 \mathrm{~nm})$, differs in comparison with dependencies of samples obtained with micro-Si (see Fig. 1,b). In these samples, the transition from the highly résistance state to the low resistance occurs at a slower rate. There is observed no sharp boundary of the percolation transition with the increase in the quantity of filler. The reason is the increase in the effective surface of the interphase polymer-Si border, in proportion to the increase in the filler's volume to $\Phi=50 \%$. The change in resistance is due to an increase in crosslinking in the polymer matrix of nanocomposites after gamma irradiation, oxidation of nano-Si particles, and an increase in $\mathrm{Si}-\mathrm{O}-\mathrm{C}$ bonds [24]. In addition, we believe that a more uniform distribution of nanoscale filler over the volume of the composite leads to a more efficient absorption of the dose by the filler and ultimately to a decrease in the effect of radiation on the matrix $[25,26]$. To study the differences in the electrical conductivity of $\mathrm{P}(\mathrm{VDF}-$ TeFE) - nano- and microcomposites obtained at two different concentrations ( 1 and 10 vol.\%) and irradiated in the $0 \ldots 300 \mathrm{kGy}$ range, the temperature dependence of their specific resistance $\left(\rho_{\mathrm{v}}\right)$ in the stable electric field was investigated (Fig. 2). Dependence of $\lg \rho_{\mathrm{v}}=f(1 / T)$ for $\mathrm{P}(\mathrm{VDF}-\mathrm{TeFE}) / \mathrm{Si}$ composites obtained with the same amount of nano- and micro-Si and irradiated at different doses and comparative analysis of activation energy $(\Delta E)$ calculated from these dependencies allows us to evaluate the exploitation characteristics and radiation resistance of composites. It is seen that the dependence $\lg \rho_{\mathrm{v}}=f(1 / T)$ of the initial $\mathrm{P}(\mathrm{VDF}-\mathrm{TeFE}) / \mathrm{Si}$ composites obtained with $1 \%$ (see Fig. 2,a) and with $10 \%$ by volume (see Fig. 2,d) nano (curve 2) and micro (curve 3 ) of the filler consists of curves, which differ from each other in resistance value by two orders of magnitude. The resistance of composites obtained by nano-Si is higher than the resistance of composites obtained with micro-Si, and in this case the specific resistance of the samples obtained with the nano-Si increases compared with polymers, while the specific resistance of the composite obtained with micro-Si decreases.

The activation energy of the conductivity $\Delta E$ was calculated for the tangent to the rectangular portion of each curve in the dependence on $\lg \rho_{\mathrm{v}}=f(1 / T)$ of both micro- and nanosized composites and the results are presented in the Table. Comparison of the curves (see Fig. 2,d,e,f; curve 2) and corresponding activation energy values (see Table) of the initial and irradiated samples of the P(VDF-TeFE)/10\% nano-Si composites in the dependence of $\lg \rho_{\mathrm{v}}=f(1 / T)$ shows that the parameters remain stable within a certain error the measured temperature range. The reason why, P(VDF$\mathrm{TeFE}$ )/nano-Si composites obtained with nano-Si are resistant to ionizing radiation, as we mentioned above, is the relatively high concentration of particles in the bulk of the composite and their uniform distribution [26]. 

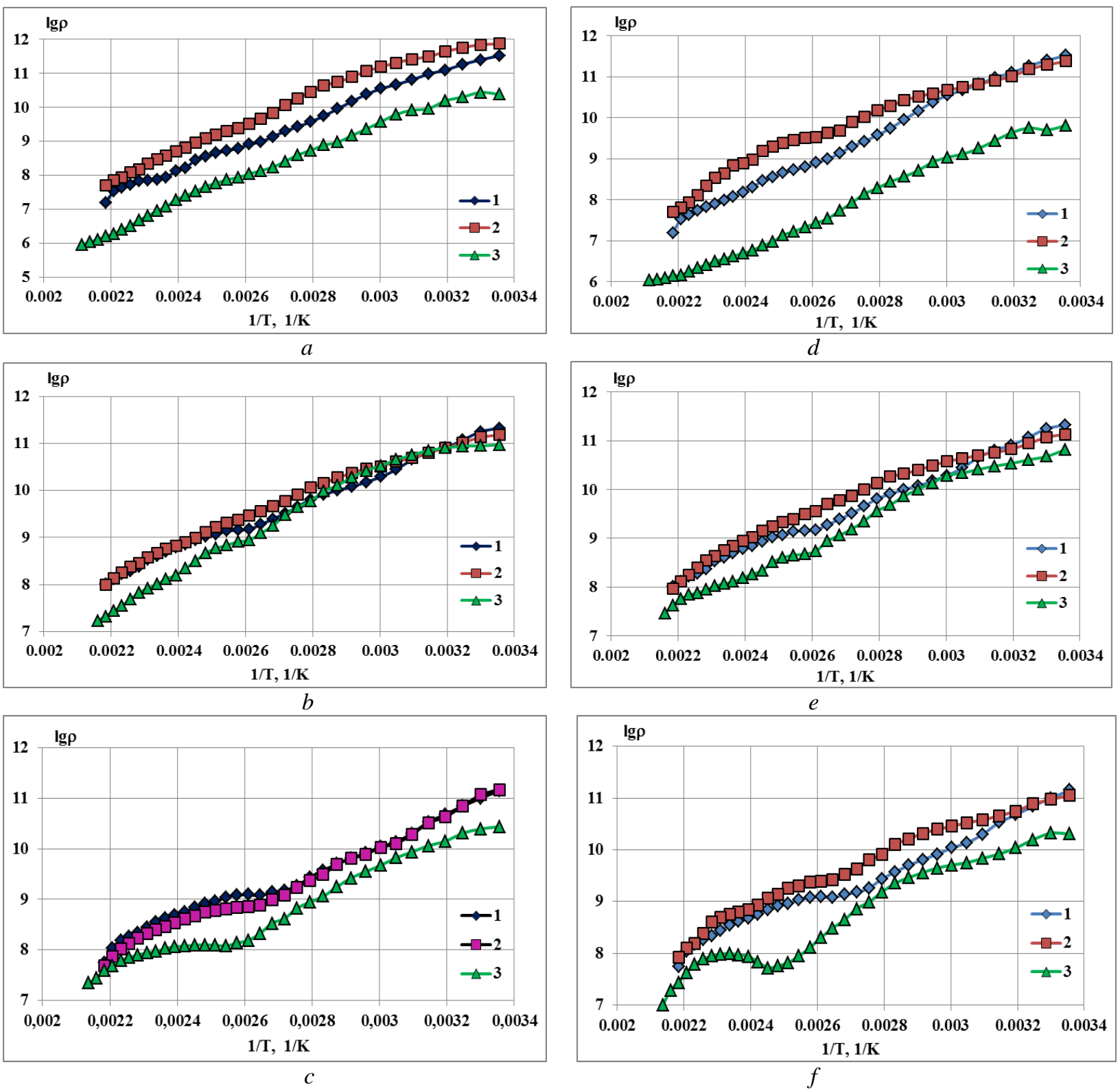

Fig. 2. Dependence $\lg \rho=f(1 / T)$ for the $1 \%(a, b, c)$ and $10 \%(d, e, f) P(V D F-T e F E) / S i$ composites and $P(V D F-T e F E)$ irradiated at different doses: $a$ - and $d$-initial; $b$-and $e-100 k G y ; c$ - and f - $300 k G y$; $1-P(V D F-T e F E) ; 2$ - nano-Si; 3 - micro-Si

The activation energy of conductivity $\Delta E$ was calculated according to the method from the literature [27] from the dependences $\lg \rho_{\mathrm{v}}=f(1 / T)$ of both microsize and nanoscale composites, and the results are presented in the Table. The same effect is also observed for $\mathrm{P}(\mathrm{VDF}-\mathrm{TeFE}) / 1 \%$ nano-Si samples which irradiated $100 \mathrm{kGy}$ dose. Comparison of the curves and values of the activation energy $\Delta E$ in the Table shows that the parameters of the composites with a content of 1 and $10 \%$ bulk nano-Si and irradiated with a dose of 100 kGy are more resistant to gamma irradiation. And the values of the irradiation dose of $100 \mathrm{kGy}$ may be adopted as a modification mode for $\mathrm{P}(\mathrm{VDF}-$ TeFE)/nano-Si composites. As can be seen from the table, $\mathrm{P}(\mathrm{VDF}-\mathrm{TeFE}) / 10 \%$ nano-Si composites can be used as resistant materials to the effects of gamma radiation. The radiation energy absorbed in the $\mathrm{P}(\mathrm{VDF}-$
TeFE)/10\% nano-Si composites, obtained on the basis of nanoscale $\mathrm{Si}$ particles, is distributed, the energy at the interfacial boundary of the polymer matrix and nanoparticles increases, and as a result the stable conductivity of the samples is provided. We believe that, during irradiation of polymer nanocomposites, the absorbed radiation energy is redistributed in the $\mathrm{P}(\mathrm{VDF}-\mathrm{TeFE}) / 10 \%$ nano-Si composites. Part of the energy supplied to the interfacial boundary of the polymer matrix and the nanoparticles increases, and part of the energy of the falling polymer matrix leads to an increase in crosslinking and, as a result, is the stability conductivity [26]. We know that, while the filler has the same quantity, the concentration of particles in the nanocomposite is relatively high compared to the microcomposite. 
The values of the activation energy $\Delta E$ of conductivity for $\mathrm{P}(\mathrm{VDF}-\mathrm{TeFE})$, initial and irradiated at different doses and $\mathrm{P}(\mathrm{VDF}-\mathrm{TeFE}) / \mathrm{Si}$ composites obtained with micro- and nanoparticles

\begin{tabular}{|c|c|c|c|c|c|}
\hline \multirow{2}{*}{ Sample } & \multirow{2}{*}{ Dose, kGy } & \multicolumn{2}{|c|}{ micro-Si } & \multicolumn{2}{|c|}{ nano-Si } \\
\hline & & $\Delta E_{1}, \mathrm{eV}$ & $\Delta E_{2}, \mathrm{eV}$ & $\Delta E_{1}, \mathrm{eV}$ & $\Delta E_{2}, \mathrm{eV}$ \\
\hline \multirow{3}{*}{$100 \% \mathrm{P}(\mathrm{VDF}-\mathrm{TeFE})$} & 0 & - & 0.33 & - & 0.33 \\
\hline & 100 & - & 0.298 & - & 0.298 \\
\hline & 300 & - & 0.27 & - & 0.27 \\
\hline \multirow{3}{*}{$\mathrm{P}(\mathrm{VDF}-\mathrm{TeFE}) / 1 \% \mathrm{Si}$} & 0 & - & 0.36 & 0.2 & 0.387 \\
\hline & 100 & 0.036 & 0.31 & 0.17 & 0.26 \\
\hline & 300 & 0.15 & 0.324 & - & 0.253 \\
\hline \multirow{3}{*}{$\mathrm{P}(\mathrm{VDF}-\mathrm{TeFE}) / 10 \% \mathrm{Si}$} & 0 & - & 0.32 & 0.18 & 0.25 \\
\hline & 100 & 0.113 & 0.298 & 0.18 & 0.25 \\
\hline & 300 & 0.165 & 0.36 & 0.18 & 0.25 \\
\hline
\end{tabular}

Transfer from microparticles to nanoparticles results in an increase in the concentration of the filler's active surface and the concentrations of $\mathrm{C}-\mathrm{O}-\mathrm{Si}$ bonds and, consequently, in a decrease in the mobility and conductivity of the polymer chains we experimentally observe [24]. The concentration of $\mathrm{C}-\mathrm{O}-\mathrm{Si}$ bonds decreases due to a decrease in the effective surface in the case of composites obtained with microparticles, and an increase in the mobility of the polymer chains and conductivity is observed, respectively, which affects the activation energy.

\section{CONCLUSIONS}

The reason for the observed changes depending on the $\lg \rho_{\mathrm{v}}=f(\Phi)$ of the irradiated composites obtained on the basis of the copolymer P(VDF-TeFE) with microand nanosized $\mathrm{Si}$ are both crosslinking in the matrix and oxidation of the filler surface, as well as the uneven distribution of absorbed energy radiation between the components of the composite.

Thus, when the filler is nanosized, the concentration becames higher and its even distribution in the volume leads to more effective absorption of the absorbed dose by the filler and, consequently, the attenuation of the radiation effect on the matrix.

The stability of the $\rho_{\mathrm{v}}$ and $\Delta E$ parameters for $\mathrm{P}(\mathrm{VDF}-\mathrm{TeFE}) / 10 \%$ nano-Si composites up to a dose of $300 \mathrm{kGy}$ can be estimated as the gamma-radiation resistance of the composites in the indicated dose range.

\section{REFERENCES}

1. Наноструктурные материаль / Под ред. Р. Ханнинка, А. Хилл. М.: Изд. «Техносфера», 2009, $488 \mathrm{c}$.

2. И.В. Бакеева. Наноструктуры: основные понятия, классификащия, способы получения. М.: МИТХТ им. М.В. Ломоносова, 2008, 68 с.

3. А.Д. Помогайло, А.С. Розенберг, И.Е. Уфлянд. Наночастицы металлов в полимерах. М.: «Химия», 2004, 672 с.

4. А.Д. Помогайло. Металлополимерные нанокомпозиты с контролируемой молекулярной архитектурой // Рос. хим. журнал (Журнал Рос. хим. общества им. Д.И. Менделеева). 2002, т. XLVI, №5, c. 64-73.

5. И.Ю. Гороховатский. Исследование стабильности электретного состояния в композитных пленках на основе полиэтилена высокого давления с наноразмерными включениями $\mathrm{SiO}_{2}$ : Автореф. дис.
.. канд. физ.-мат. н. Санкт-Петербург: ООО «АБЕВЕГА», 2009, 16 с.

6. В.Б. Пикулев, С.В. Логинова, В.А. Гуртов, Влияние естественного и стимулированного окисления на люминесцентные свойства нанокомпозитов «кремний-целлюлоза»// Письма 8 ЖТФ. 2012, т. 38, в. 15 , с. 74-81.

7. В.Г. Соловьев, С.Д. Ханин. Размерные эффекты в наноструктурах на основе регулярных пористых матриц // Известия Российского государств. педагогического университета им. А.И. Гериена: Естест. и точные науки. 2004, №4(8), c. 84-93.

8. С.Н. Ткаченко, О.С. Гефле, С.М. Лебедев. Исследование свойств поливинилиденфторида, модифицированного наночастицами никеля // Пластические массы. 2008, №2, с. 28-32.

9. Houda Rekik, Zied Ghallabi, Isabelle Royaud, Mourad Arous, Gérard Seytre, Giséle Boiteux, Ali Kallel. Dielectric relaxation behaviour in semicrystalline polyvinylidene fluoride (PVDF)/ $/ \mathrm{TiO}_{2}$ nanocomposites // Composites: Part B. 2013, v. 45, p. 1199-1206.

10. Javier Arranz-Andres, Nuria Pulido-Gonzalez, Pilar Marin, Ana M. Aragon, Maria L. Cerrada. Electromagnetic shielding features in lightweight pvdfaluminum based nanocomposites // Progress in Electromagnetics Research B. 2013, v. 48, p. 175-196.

11. A.M. Magerramov, M.A. Nuriyev, I.A. Veliev, S.I. Safarova. Coronoelectrets Based on Polypropylene Composites Dispersed by a TlInxCe(1-x)Se2 Semiconductor Filler // Surface Engineering and Applied Electrochemistry. 2010, v. 46, N 2, p. 169-172.

12. P. Thomasa, S. Satapathy, K. Dwarakanath, K.B.R. Varma. Dielectric properties of Poly (vinylidene fluoride)/ CaCu3Ti4O12 nanocrystal composite thick films // EXPRESS Polymer Letters. 2010, v. 4, N 10, p. 632-643.

13. А.В. Сухинина. Разработка радиаџионносшиваемых наполненных композиций на основе сэвилена для кабельных термоусаживаемых изделий: Автореф. дис. ... канд. физ.-мат. н. М.: ООО «Петроруш», 2009, 19 с.

14. С.А. Хатипов, Е.М. Конова, Н.А. Артамонов. Радиационно-модифицированный политетрафторэтилен: структура и свойства // Рос. хим. журнал (Журнал Рос. хим. общества им. Д.И. Менделеева). 2008, т. LII, №5, с. 64-72. 
15. A.M. Magerramov, M.A. Nuriyev, F.I. Akhmedov, and I.M. Ismailov. Radiothermoluminescence of $\gamma$ irradiated Composites of Polypropilene and Dispersed Oxides // Surface Engineering and Applied Electrochemistry. 2009, v. 45, N 5, p. 437-440.

16. Zelimir Jelcic, Franjo Ranogajec. High impact polystyrene modified by ionizing $\gamma$-radiation // Polimeri. 2010, v. 31, N 2, p. 52-58.

17. К.К. Аметов, Б. Лаипов, С.М. Жолдасова, А.Г. Лаврушко и др. Электропроводность полимерных композитов. Композиты на основе пропилена $и$ кремния: Препринт №Р-9-308, ИЯФ АН УзССР, $1987,10 \mathrm{c}$.

18. В.И. Фистул. Перколяция тока в полимерополупроводниковой структуре // ФТП. 1993, т. 27, в. $11 / 12$, с. $1788-1794$.

19. М.И. Василевский, А.М. де Паула, Е.И. Акинкина, Е.В. Анда. Влияние дисперсии размеров на оптическое поглощение системы полупроводниковых квантовых точек // ФТП. 1998, т. 32, №11, c. 1378-1383.

20. В.И. Вигдорович,

С.В. Мищенко, Н.В. Шель. Пути прогнозирования наличия наноразмерных эффектов наноматериалов // Вестник ТГТУ. 2009, т. 15, №3, с. 561-571.

21. Д.М. Кульбацкий, Н.М. Ушаков, Г.Ю. Юрков, В.Я. Подвигалкин. Исследование оптических характеристик композитных материалов на основе наночастиц сульфида кадмия, стабилизированных в матрице полиэтилена высокого давления // Оптика и спектроскопия. 2009, т. 106, №5, с. 780-784.

22. В.А. Соцков. О влиянии контактного сопротивления частиц на интервал перколяции в макронеупорядоченных системах проводникдиэлектрик // Журнал технической физики. 2004, т. 74 , в. 11 , с. $107-110$;

23. В.Е. Гуль, Л.З. Шенфиль. Электропроводящие полимерные композищии. М.: «Химия», 1984, $240 \mathrm{c}$.

24. A.M. Maharramov, I.M. Nuruyev, R.N. Mehdiyeva, M.A. Nuriyev. The IR-spectroscopy and electrical properties of the composites on the basis of $\mathrm{P}(\mathrm{VDF}-\mathrm{TeFE}) /$ nano-Si // Journal of Radiation Researches. 2017, v. 4, N 2, p. 35-46.

25. И.М. Нуриев, А.М. Магеррамов, Р.Н. Мехтиева, В.Г. Гасымова. Изменение проводимости гамма-облученных микро- и нанокомпозитов П(ВДФ-ТеФЭ)/Si // VIII Respublikanskiy Konfrans "Radiasionnie issledovaniya i ix prakticeskie aspekti", 20-21 Noyabr, 2013, Baku, Azerbaycan, s. 63-64.

26. Д.В. Алявдин, А.Р. Клестов, А.А. Шестаков. Влияние наполнителей на химические процессы при радиационной модификации полиолефинов // Фазовые переходы, упорядоченные состояния $u$ новые материальь. 2012, №11, с. 1-5

27. А.А. Позняк, В.А. Полубок. Электрофизические характеристики диэлектриков: Методическое пособие к лабораторным работам. Минск, 2009,48 c.

Article received 29.07.2019

\title{
ЭЛЕКТРИЧЕСКИЕ СВОЙСТВА ГАММА-МОДИФИЦИРОВАННЫХ КОМПОЗИТОВ СОПОЛИМЕРА ПОЛИВИНИЛИДЕНФТОРИДУ С ТЕТРАФТОРЭТИЛЕНОМ И КРЕМНИЕМ
}

\author{
И.М. Нуруев
}

Исследованы концентрационные и температурные зависимости электрических свойств композитов, полученных на основе сополимера поливинилиденфторида с тетрафторэтиленом P(VDF-TFE) с нано- и микрочастицами кремния, и изучено влияние на них гамма-излучения. Показано, что причиной изменения в концентрационных и температурных зависимостях электрических свойств облученных композитов P(VDF$\mathrm{TeFE} / \mathrm{Si}$ кроме сшивания и деструкции является и неравномерное распределение энергии поглощенного излучения между компонентами композитного материала.

\section{ЕЛЕКТРИЧНІ ВЛАСТИВОСТІ ГАММА-МОДИФІКОВАНИХ КОМПОЗИТІВ СОПОЛІМЕРА ПОЛІВІНІЛІДЕНФТОРИДУ 3 ТЕТРАФТОРЕТІЛЕНОМ І КРЕМНІЕМ}

\section{I.M. Нуруєв}

Досліджено концентраційні і температурні залежності електричних властивостей композитів, отриманих на основі сополімера полівініліденфториду з тетрафторетіленом P(VDF-TFE) з нано- і мікрочастинками кремнію, і вивчено вплив на них гамма-випромінювання. Показано, що причиною зміни в концентраційних і температурних залежностях електричних властивостей опромінених композитів $\mathrm{P}(\mathrm{VDF}-\mathrm{TeFE}) / \mathrm{Si}$ крім зшивання і деструкції $є$ і нерівномірний розподіл енергії поглиненого випромінювання між компонентами композитного матеріалу. 